\title{
NUTCRACKER SENDROMU
}

\author{
Engin MELEK
}

Çukurova Üniversitesi Tıp Fakültesi, Çocuk Sağlığı ve Hastalıkları Anabilim Dalı, Çocuk Nefroloji Bilim Dalı, Adana, Türkiye

Nutcracker Sendromu (NCS) sol renal vene bası sonucu ortaya çıkan bir klinik tablodur. Sendrom ilk olarak 1937 yılında Grantin tarafından tanımlanmışıı. En sık sol renal venin aorta ile süperior mezenterik arter arasında sıkışması sonucunda görülür ve bu tip "anterior tip" olarak tanımlanır. Daha az sıklıkla retroaortik sol renal venin aorta ile vertebra arasında sıkışması sonucu "posterior NCS" görülebilir. Sol renal vene basının kan akımını engellemesi sonucu ven içerisinde oluşan basınç artışı sol böbrekte konjesyona yol açmaktadır $(1,2)$.

Nutcracker Sendromlu hastalar asemptomatik hematüriden ağır pelvik konjesyona kadar değişen çok farklı klinik tablolarla karşımıza çıkabilir. Hastalar hematüri, ortostatik proteinüri, yan ağrısı, karın ağrısı, varikosel, dismenore, halsizlik ve yorgunluk gibi belirti ve bulgularla başvurabilir. Nadirende Henoch-Schönlein purpura, IgA nephropati, membranöz nefropati ve nefrolitiazis ile başvuran vakalar tanımlanmıştı. Genellikle ince uzun yapılı ve yağ dokusu az kişilerde görülmektedir. Literatürde NCS'lu hastaların düşünüldüğünden daha fazla olduğu belirtilmektedir. Bunun nedeni bu hastalık konusunda farkındalığımızın az olmasıdır. Oysa ki NCS tanıında ilk ve en önemli basamak bu sendromdan şüphelenilmesidir $(2,3)$.

Nutcracker Sendromu tanısını dopler ultrasonografi, CT anjiografi, MR anjiografi ve retrograd sol renal venografi gibi farklı görüntüleme yöntemleri ile konulabilir. Retrograd venografi NCS tanısında altın standart olmasına karşın invazif olması nedeniyle ağır vakalarda tercih edilmektedir. Doppler ultrasonografi invazif olmaması nedeniyle NCS şüphesi olan hastalarda ilk olarak tercih edilmektedir (3).

Dergimizde yayınlanan Çakıcı EK ve ark. (4) çalışmalarında 2015-2018 yılları arasında NCS tanısıyla izledikleri, semptomatik ve asemptomatik olarak iki gruba ayırdıkları 41 hastanın klinik belirtileri ile doppler ultrasonografi bulguları arasındaki ilişkiyi araştırdıar. Bu çalışmada doppler ultrasonografinin bu hastalarda ilk tercih edilen yöntem olarak önerebileceklerini belirtmektedirler. Ayrıca izole hematüri, proteinüri veya sol yan ağrısı ile başvuran hastalarda böbrek biyopsisi yapmadan önce NCS tanısının ekarte edilmesi gerektiğini vurgulamaktadırlar (4).

\section{KAYNAKLAR}

1. Avgerinos ED, McEnaney R, Chaer RA. Surgical and endovascular interventions for nutcracker syndrome. Semin Vasc Surg 2013;26:170-7.

2. Alaygut D, Bayram M, Soylu A, Cakmakcı H, Türkmen M, Kavukcu S. Clinical course of children with nutcracker syndrome. Urology 2013;82:686-90.

3. Gulleroglu K, Gulleroglu B, Baskin E. Nutcracker syndrome. World J Nephrol 2014;3: 277-81.

4. Çakıcı EK, Yazılıtaş F, Çınar HG, Can G, Kurt Şükür ED, Güngör T, et al. Çocuklarda Nutcracker Sendromu: Doppler Ultrasonografinin Semptomatik Hastalardaki Rolü. Türkiye Çocuk Hast Derg 2019;13:348-53. 